\title{
CONVERSION OF THE LOW QUALITY INDONESIAN NATURALLY-OCCURRING MINERALS INTO SELECTIVE TYPE OF ZEOLITES BY SEED-ASSISTED SYNTHESIS METHOD
}

\author{
Rino R. Mukti ${ }^{1, *}$, Shofarul Wustoni ${ }^{1}$, Agus Wahyudi ${ }^{2}$, and Ismunandar ${ }^{1}$ \\ ${ }^{1}$ Division of Inorganic and Physical Chemistry, Faculty of Mathematics and Natural Sciences, \\ Institut Teknologi Bandung, Jl. Ganesha no. 10 Bandung 40132, Indonesia \\ ${ }^{2} R \& D$ Center for Mineral and Coal Technology (TEKMIRA), Ministry of Energy and Mineral Resources, \\ Republic of Indonesia, Jl. Jendral Sudirman no. 623 Bandung 40211, Indonesia
}

Received April 18, 2013; Accepted October 1, 2013

\begin{abstract}
An X-ray diffraction (XRD) revealed that Indonesian naturally-occurring mineral from Nanggung, Bogor shows to be a low quality product as it does not seem to contain any zeolite materials. As located in the volcanic area, Indonesia essentially has abundant source of natural zeolites and the country has put much efforts on these treasured materials for export commodity. In order to bring the local natural mineral into high value and to discover whether the mineral has at least zeolitic fragments, we have implemented seed-assisted synthesis to see the possibility of growing zeolite and turn this mineral into high quality. In principle, once the mineral has zeolitic fragment or nuclei, recrystallization of the mineral may occur. By utilizing this mineral as seed in aluminosilicate mother solution, selective mordenite-type (MOR) zeolite can be obtained after hydrothermal treatment. Characterization by XRD showed that this MOR zeolite has high crystallinity and scanning electron microscopy (SEM) depicted the crystal morphology. The natural mineral is conclusively essential for the formation of MOR zeolite by seeding the aluminosilicate mother solution. In the absence of aluminosilicate mother solution, natural mineral can be recrystallized into selective analcime-type (ANA) zeolite. MOR zeolite is known to be useful for several applications such as catalysis whereas ANA zeolite has been considered to be less potential due to relatively small microporosity.
\end{abstract}

Keywords: zeolite; mordenite; analcime; seed; mineral; crystal; hydrothermal; Indonesia

\begin{abstract}
ABSTRAK
Hasil analisis difraksi sinar X (XRD) menunjukkan bahwa mineral alam Indonesia yang berasal dari daerah Nanggung, Bogor memiliki kualitas yang rendah dimana tidak terdapat kandungan material Zeolit. Indonesia yang terletak di kawasan vulkanik memiliki sumber zeolit alam dalam jumlah yang besar dan negara ini telah berusaha untuk menjadikan material ini sebagai komoditi ekspor. Untuk meningkatkan kualitas serta menggali lebih jauh lagi apakah mineral alam ini memiliki setidaknya fragmen atau benih Zeolit, kami telah menerapkan metode sintesis dengan bantuan benih untuk melihat kemungkinan terbentuk atau menumbuhkan material Zeolit dan memberikan mineral ini suatu nilai tambah. Pada prinsipnya, ketika mineral alam memiliki fragmen atau benih Zeolit, rekristalisasi mineral dapat dilakukan. Dengan menggunakan mineral alam sebagai benih Zeolit tipe Mordenit dapat dihasilkan setelah proses hidrotermal. Karakterisasi dengan XRD menunjukkan bahwa zeolit tipe Mordenit yang dihasilkan memiliki kristalinitas yang tinggi, selain itu karakterisasi dengan mikroskopi elektron (SEM) menunjukkan morfologi kristal Zeolit. Hasil ini menunjukkan bahwa keberadaan mineral alam sebagai benih dalam larutan induk aluminosilikat pada metode sintesis penelitian ini, sangat berperan penting dalam pembentukan material Zeolit tipe Mordenit. Sedangkan tanpa adanya larutan induk aluminosilikat, mineral alam tersebut hanya dapat direkristalisasi menjadi material Zeolit tipe Analsim. Material zeolit tipe Mordenit memiliki aplikasi yang lebih luas dan bermanfaat contohnya sebagai katalis, dibandingkan material Zeolit tipe Analsim yang kurang potensial pemanfaatannya karena ukuran mikroporinya yang relatif kecil.
\end{abstract}

Kata Kunci: zeolit; mordenit; analsim; benih; mineral; kristal; hidrotermal; Indonesia

* Corresponding author. Tel/Fax : +62-22-2502103/2504154

Email address : rino@chem.itb.ac.id

Rino R. Mukti et al. 


\section{INTRODUCTION}

Zeolites are microporous crystalline aluminosilicate materials that occur as natural minerals or as a result from laboratory synthesis [1-2]. Today, there are over 200 types of zeolites differing upon frameworks and elemental composition. The porosity of zeolite is in a molecular scale so they can be used to host a guest molecule in a selective manner of certain catalytic processes. In their acid form, zeolites are known as shape and size selective catalyst and considered as the most important heterogeneous catalyst in the industry [3]. For example, the world's gasoline is produced by fluidized catalytic cracking of petroleum using zeolite catalysts [4]. In view of the industrial importance of zeolites and also due to the scientific interest in developing such an economical process, considerable effort has been directed into zeolite synthesis.

Low $(\mathrm{Si} / \mathrm{Al}<2)$ and medium $(2<\mathrm{Si} / \mathrm{Al}<5)$ silica zeolites can be directly synthesized without using such organic compounds, however high (Si/Al > 5) silica zeolites are subject to the synthesis using organic compounds for facilitating void filling, structure-directing or templating pathway [2]. These days, the preference of synthesizing all kind of zeolites is to avoid the use of organic compounds due to high cost and to reduce $\mathrm{CO}_{2}$ emission into atmosphere. The latter may be the situation when the organic compounds from the zeolite framework are removed by calcination. Seed-assisted synthesis is one of methods that have been developed to exclude the organic in zeolite precursor. High silica zeolites such as BEA [5-6], MTW [7], FER [8], ECR-1 [9], ZSM-34[10] can be synthesized by the help of their corresponding seed of up to $10 \%$ weight. Moreover, MFI zeolite can be synthesized in the absence of organic as well as seed [11].

As located in volcanic area, Indonesia has abundant source of naturally-occurring minerals that is presumably to contain several zeolite frameworks or zeolitic building blocks in such a low quality, for example in Malang, Wonosari and Bogor [12]. The quality of such zeolite can be determined by the sole presence of certain structure (topology). However in natural minerals, the possibility of having selective zeolite topology is almost impossible. Mordenite (MOR), analcime (ANA) and clinoptilolite (HEU) are the zeolite topologies that are often found in nature as mixtures. Among these topologies, MOR is of crucial natural zeolite that is also further developed by synthetic method [13-15]. Having various topologies in minerals, the performance towards ion exchange capability and molecular sieve selectivity is not optimal. To this end, specifically, the Indonesian government has the policy to increase the quality of export product particularly on natural zeolite starting in the year of 2014 [16]. This can be done by making the natural zeolite to consist only certain type of (selective) zeolite topology [17].

Our current research here has the objective of bringing the low quality local natural mineral into high value by recrystallizing towards the growth of selective zeolite via seed-assisted synthesis method. The utilization of natural minerals as seed is based on the assumption of having zeolitic fragments in the form of most probably secondary building units/blocks. Having a successful seed-assisted synthesis, one may use this method as a tool to determine the unknown crystalline phase or even amorphous phase in natural minerals. The resulting zeolite topology may provide an insight of somewhat predicting the zeolitic secondary building block contained in natural mineral. We are of interest to obtain selective MOR-type zeolite since this topology can be utilized in various industrial applications such as gas separation, catalysis, semiconductor and chemical sensor [18-19]. Several catalytic reactions such as hydro isomerization, alkylation, cracking and reforming have proved potency of this 12-membered-ring zeolite with pore dimension of $0.64 \times 0.70 \mathrm{~nm}$ (running along the $c$-axis) and $0.26 \times 0.57 \mathrm{~nm}$ (running along the $b$ axis) [20]. By increasing the value of our natural mineral resource, we expect that the quality of export product can be improved.

\section{EXPERIMENTAL SECTION}

\section{Materials}

Naturally-occurring minerals were obtained from Nanggung nearby Bogor, West Java, Indonesia. Tetraethyl orthosilicate (TEOS, $\left.\mathrm{Si}\left(\mathrm{OC}_{2} \mathrm{H}_{5}\right)_{4}\right)$ was purchased from Aldrich. Aluminum hydroxide $\left(\mathrm{Al}(\mathrm{OH})_{3}\right)$ was purchased from Merck. Sodium hydroxide $50 \%(\mathrm{w} / \mathrm{v})$ was used in the experiment that is prepared by dissolving sodium hydroxide pellet. Unless stated otherwise, all chemicals were used as received.

\section{Characterizations}

To elucidate zeolite topology, all obtained samples were characterized by powder X-ray diffraction (XRD). XRD patterns were recorded on diffractometer with $\mathrm{Cu}$ Ka radiation. Crystal morphology was observed by field-emission scanning electron microscopy (SEM). SEM images were taken at an accelerating voltage of $6 \mathrm{kV}$. Prior to the observation, samples were sputtered using $\mathrm{Pt}$ on a sputtering instrument. 
Table 1. Starting molar composition of mixtures applied in the series of seeded synthesis

\begin{tabular}{cccc}
\hline Si/Al initial & $\mathrm{NaOH} / \mathrm{Si}$ & $\mathrm{H}_{2} \mathrm{O} / \mathrm{Si}$ & Temp, time \\
\hline 25 & 0.24 & 24 & $170{ }^{\circ} \mathrm{C}, 5$ days \\
30 & 0.24 & 24 & $170^{\circ} \mathrm{C}, 5$ days \\
\hline
\end{tabular}

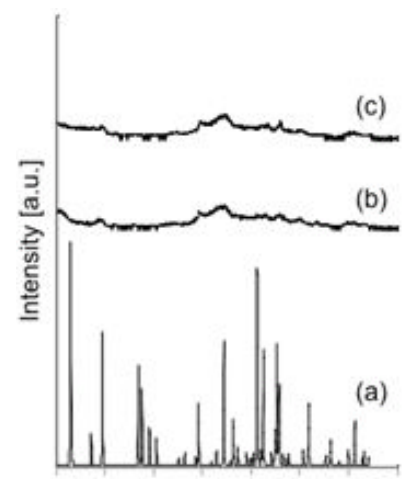

$\begin{array}{llllllll}5 & 10 & 15 & 20 & 25 & 30 & 35 & 40\end{array}$ $2 \theta$ (Cu K a) [ $\left.{ }^{\circ}\right]$

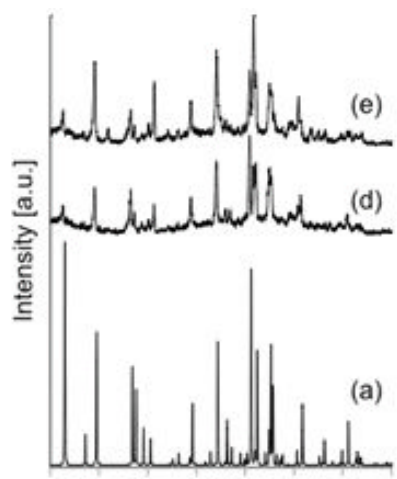

$\begin{array}{llllllll}5 & 10 & 15 & 20 & 25 & 30 & 35 & 40\end{array}$ $2 \theta$ (Cu K a) [ $\left.{ }^{\circ}\right]$
Fig 1. XRD pattern of (a) MOR references of simulated data taken from IZA website, (b) as-taken natural minerals, (c) calcined natural minerals and (d), and (e)products of seed-asssisted synthesis of $\mathrm{Si} / \mathrm{Al}$ ratio = 25 and $\mathrm{Si} / \mathrm{Al}=30$

\section{Procedure}

\section{Seed-assisted synthesis of zeolite using naturally- occurring minerals}

$0.16 \mathrm{~g} \mathrm{Al}(\mathrm{OH})_{3}, 11.31 \mathrm{~g}$ TEOS and $2.00 \mathrm{~g} \mathrm{NaOH}$ $50 \%(\mathrm{w} / \mathrm{v})$ were mixed with $21.52 \mathrm{~g}$ of water. To this aluminosilicate mother solution, $1.62 \mathrm{~g}$ of Indonesian naturally-occurring minerals was added under vigorous stirring at room temperature. Subsequently, the mixture in the form of gel was transferred in a Teflon-lined stainless steel autoclave at $170{ }^{\circ} \mathrm{C}$ for 5 days. The resulting precipitate was filtered, washed and dried in an oven at $60{ }^{\circ} \mathrm{C}$ for $6 \mathrm{~h}$. Following this seeded synthesis procedure; series of samples were prepared by varying $\mathrm{Si} / \mathrm{Al}$ ratio of starting molar composition and hydrothermal temperature (Table 1).

\section{RESULT AND DISCUSSION}

Fig. 1 shows the XRD pattern of as-taken and calcined natural mineral. It can be observed that the natural mineral contains very low crystallinity. It is hard to speculate typical zeolite topologies from the diffractogram peaks. Calcining the natural minerals sample using muffle furnace under air at $170{ }^{\circ} \mathrm{C}$ for $65 \mathrm{~h}$, does not increase the crystallinity. The calcined sample shows an identical pattern to the parent sample. This indicates that the structure has been stable at its current form. The natural mineral can be dissolved in alkaline
Table 2. Starting molar composition of mixtures applied in the series of non-seeded synthesis

\begin{tabular}{cccc}
\hline $\mathrm{Si} / \mathrm{Al}$ initial & $\mathrm{NaOH} / \mathrm{Si}$ & $\mathrm{H}_{2} \mathrm{O} / \mathrm{Si}$ & Temp, time \\
\hline 25 & 0.24 & 24 & $170{ }^{\circ} \mathrm{C}, 5$ days \\
30 & 0.24 & 24 & $170{ }^{\circ} \mathrm{C}, 5$ days \\
\hline
\end{tabular}
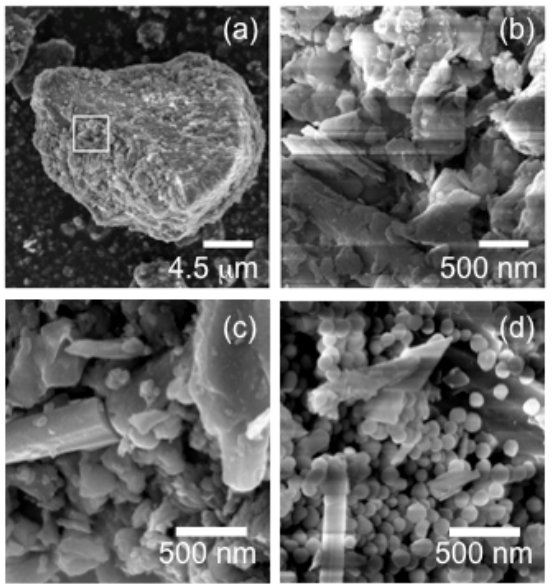

Fig 2. SEM images of (a, b) natural minerals and (c, d) as-synthesized MOR zeolites; (b) magnified image from (a) with location shown as square line. (c) MOR zeolite with Si/Al ratio of 25 and (d) Si/Al ratio of 30

solution of aluminosilicate. By hydrothermally treating this solution at $170{ }^{\circ} \mathrm{C}$ for 5 days, highly crystalline MOR zeolite can be selectively obtained (Fig. 1d, e). The natural mineral seems to function as seed in the aluminosilicate solution during the crystallization of MOR zeolite. MOR zeolite can also be obtained after varying the starting Si/Al ratio from 25 to 30 .

Crystal morphology of the resulting MOR zeolite is presented in Fig. 2. Natural mineral shows bulk particles with rough surfaces. From the magnified image, it is seen that the crystal shape is irregular. Varying the Si/Al ratio seems to alter the morphology of MOR zeolite. Sample with Si/Al ratio of 25 has irregular crystal shape similar to the natural minerals but sample with $\mathrm{Si} / \mathrm{Al}$ ratio of 30 shows regular spherical crystal with size around $50 \mathrm{~nm}$. This nanocrystal might contain MOR zeolite framework since the XRD pattern shows only the presence of MOR lattice ordering. However, selected electron diffraction during the transmission electron microscopy experiment must be conducted to further verify the lattice fringes of MOR zeolite within the nanocrystals.

Hydrothermal treatment of non-seeded solution (in the absence of natural mineral) was also conducted to see the importance of having natural mineral in the formation of MOR zeolite. The results were compared to the seeded experiments in a systematic variation of molar compositions under various temperature and synthesis time (Table 3). However, the non-seeded 


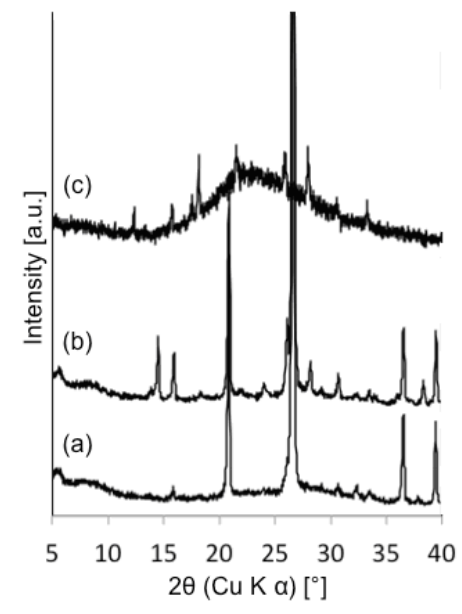

Fig 3. XRD diffractograms of the non-seeded synthesis termed as (a) unknown A, (b) unknown $B$ and (c) unknown $C$ pattern (Please see Table 3 for further description)

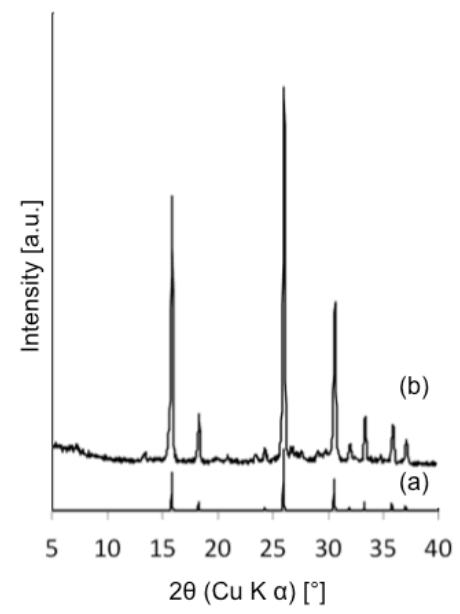

Fig 4. XRD pattern of (a) simulated ANA-type zeolite and (b) hydrothermally treated the dissolved natural mineral resulting in ANA-type zeolite

Table 3. Series of experiments comparing the molar ratio recipe and final products of seeded and non-seeded synthesis inthe present work.

\begin{tabular}{ccccccc}
\hline Entry & Seed & Si/Al initial & $\mathrm{NaOH} / \mathrm{Si}$ & $\mathrm{H}_{2} \mathrm{O} / \mathrm{Si}$ & Temp, time & Results \\
\hline 1 & No & 25 & 0.24 & 24 & $170{ }^{\circ} \mathrm{C}, 5$ days & UnknownA \\
2 & Natural mineral & 25 & 0.24 & 24 & $170{ }^{\circ} \mathrm{C}, 5$ days & MOR \\
3 & No & 30 & 0.24 & 24 & $170{ }^{\circ} \mathrm{C}, 5$ days & UnknownB \\
4 & Natural mineral & 30 & 0.24 & 24 & $170{ }^{\circ} \mathrm{C}, 5$ days & MOR \\
5 & No & 40 & 0.55 & 20 & $140{ }^{\circ} \mathrm{C}, 3$ days & UnknownC \\
6 & Entry 4 & 40 & 0.55 & 20 & $140{ }^{\circ} \mathrm{C}, 3$ days & MOR \\
7 & No & 50 & 0.55 & 20 & $140^{\circ} \mathrm{C}, 3$ days & Amorphous \\
8 & Entry 4 & 50 & 0.55 & 20 & $140{ }^{\circ} \mathrm{C}, 3$ days & MOR \\
\hline
\end{tabular}

recipe resulted in unknown structure of materials (Fig. 3). We have qualitatively verified that none of the typical natural zeolite topologies such as MOR, ANA and HEU represents the fingerprint of the resulting XRD patterns. Furthermore, none of the typical synthetic zeolite topologies such as MFI, LTA, FAU or BEA can be matched with the obtained diffractograms. Therefore, detailed analysis on XRD pattern by employing several fitting techniques has to be performed in order to determine the lattice ordering. This is the proposal of the next research project. We currently term these resulting products as unknown $\mathrm{A}, \mathrm{B}$ and $\mathrm{C}$. We observe that there are several parameters that is important to conduct recrystallization of natural mineral into selective type of zeolite, e.g. MOR. The presence of aluminosilicate solution is needed particularly to adjust the zeolite requirement for Si/Al ratio and alkalinity. The addition of $\mathrm{NaOH}$ in the aluminosilicate mother solution is mainly used to dissolve the natural mineral and balance the charge of the resulting zeolite framework.

MOR zeolite resulted from the seed-assisted synthesis can also be used as seed in a new hydrothermally treated aluminosilicate solution. In the absence of MOR zeolite seed, hydrothermally treating this solution with $\mathrm{Si} / \mathrm{Al}$ ratio of 40 and 50 gave unknown $\mathrm{C}$ and amorphous, respectively. Interestingly, MOR zeolite can be synthesized using even lower temperature $\left(140{ }^{\circ} \mathrm{C}\right)$ and shorter synthesis time (3 days) (See Table 3). The formation of MOR zeolite by hydrothermally treating the natural mineral in fact, still requires aluminosilicate solution. In the absence of aluminosilicate solution, recrystallizing the dissolved minerals in alkaline solution at $170{ }^{\circ} \mathrm{C}$ for 5 days resulted in analcime (ANA) zeolite.

From the success of selectively recrystallizing MOR zeolite from natural minerals source, we have several points to discuss, particularly on the formation mechanism. We assume that our natural mineral obtained from Nanggung nearby Bogor has at least secondary building units (SBU) or composite building units (CBU) of MOR zeolite. Although the presence of either SBU or CBU as part of the formation mechanism is still not principally well-understood, we speculate that this component might exist in our gel solution. This assumption can be supported by the experimental data in which the absence of seed could not stimulate the formation of MOR zeolite. In order to further assure that the contribution of seed of MOR zeolite lead to the 
selective crystallization of MOR zeolite, we applied reseed-assisted synthesis by means of utilizing the assynthesized MOR product as new seed. It is seen that MOR zeolite can only be synthesized when seed is utilized. In addition, the use of silica and alumina source in the form of aluminosilicate solution is of crucial to adjust the desired characteristic for growing certain type of zeolite. The absence of additional aluminosilicate solution yields other type of zeolite (ANA) that is sometimes contained in natural mineral resources.

\section{CONCLUSION}

The low quality naturally-occurring minerals has been converted into high quality crystalline zeolite materials with single topology of either MOR-type or ANA-type by means of hydrothermally treating the seedassisted solution and the alkaline solution of dissolved natural mineral, respectively. The absence of seed in a hydrothermal treatment of aluminosilicate solution with series of molar compositions, synthesis temperature and time leads to an unknown structures of crystalline materials. This indicates that the seed-assisted synthesis method plays significant role particularly to crystallize MOR zeolite. Having known the final zeolite topology of natural mineral, one may assume the presence of SBU of zeolite in which it is important to broaden the design of new target zeolite. The key factor in obtaining the desired zeolite phase can be initiated by knowing common SBU among several zeolite topologies. The novel route towards desired zeolite phase could be hypothesized by building up specific structures of SBU via bottom-up approach [21]. MOR zeolite has been one of important zeolites that are implemented in several industrial catalytic processes, therefore scale-up synthesis of MOR zeolite via this route may add up the benefit of exploiting our local mineral resources.

\section{ACKNOWLEDGEMENT}

This work was partially supported by research grant "Ikatan Alumni ITB". RRM is grateful for the program I-MHERE from the Faculty of Mathematics and Natural Sciences to partially fund the participation in the International conference. We are grateful to Dr. Philippe St. Cricq Riviere and Prof. Tatsuya Okubo (The University of Tokyo) for use of the FE-SEM instrument.

\section{REFERENCES}

1. Corma, A., 1997, Chem. Rev., 97, 6, 2373-2419.

2. Davis, M.E., and Lobo, R.F., 1992, Chem. Mater., 4, 4, 756-768.
3. Corma, A., 2003, J. Catal., 216, 1-2, 298-312.

4. Cundy, C., and Cox, P.A., 2003, Chem. Rev., 103, 3, 663-701.

5. Kamimura, Y., Chaikittisilp, W., Itabashi, K., Shimojima, A., and Okubo, T., 2010, Chem. Asian J., 5, 10, 2182-2191.

6. Xie, B., Song, J., Ren, L., Ji, Y., Li, J., and Xiao, F-S., 2008, Chem. Mater., 20, 14, 4533-4535.

7. Kamimura, Y., Itabashi, K., and Okubo, T., 2012, Microporous Mesoporous Mater., 147, 149-156.

8. Zhang, H., Guo, Q., Ren, L., Yang, C.G., Zhu, L.F., Meng, X., Li, C., Xiao, F.S., 2011, J. Mater. Chem., 21, 26, 9494-9497.

9. Song, J., Dai, L., Ji, Y., and Xiao, F-S., 2006, Chem. Mater., 18, 2, 2775-2777.

10. Wu, Z., Song, J., Ji, Y., Ren, L., and Xiao, F-S., 2008, Chem. Mater., 20, 2, 357-359.

11. Shiralkar, V.P., and Clearfield, A., 1989, Zeolites, 9, 5, 363-370.

12. Husaini, Suardi, N.A., Permana, D., and Rustendi, T., 2005, Penambangan dan Pengolahan Zeolit di Indonesia, Puslitbang Teknologi Mineral dan Batubara, Bandung, 9-10.

13. Lu, B., Oumi, Y., Itabashi, K., and Sano, T., 2005, Microporous Mesoporous Mater., 81, 1-3, 365-374.

14. Shao, C., Kim, H-Y., Li, X., Park, S-J., and Lee, DR., 2002, Mater. Lett., 56, 1-2, 24-29.

15. Paixão, V., Ana, P.,Carvalho, A.P., Rocha, J., Fernandes, A., Martins, A., 2010, Microporous Mesoporous Mater., 131, 350-357.

16. (a) UU RI Nomor 4 Tahun 2009 tentang Pertambangan Mineral dan Batubara (b) Peraturan Menteri ESDM RI Nomor 7 tahun 2009 tentang Peningkatan Nilai Tambah Mineral melalui Kegiatan Pengolahan dan Pemurnian Mineral (c) Instruksi Presiden RI Nomor 3 tahun 2013 tentang Percepatan Peningkatan Nilai Tambah Mineral melalui Pengolahan dan Pemurnian di Dalam Negeri.

17. Wustoni, S., Mukti, R.R., Wahyudi, A., and Ismunandar, 2011, Jurnal Matematika \& Sains, 16, $3,158-160$.

18. Gilbert, J.E., and Mosset, A., 1998, Mater. Res. Bull., 33, 7, 997-1003.

19. Bajpai, P.K., 1986, Zeolites, 6, 1, 2-8.

20. Fernandes, L.D., Monteiro, J.L.F., Sousa-Aguiar, E.F., Martinez, A., and Corma, A., 1998, J. Catal., $177,2,363-377$.

21. Itabashi, K., Kamimura, Y., Iyoki, K., Shimojima, A., and Okubo, T., 2012, J. Am. Chem. Soc., 134, 28, 11542-11549. 